\title{
Myosin Light Chain Kinase, Smooth Muscle
}

National Cancer Institute

\section{Source}

National Cancer Institute. Myosin Light Chain Kinase, Smooth Muscle. NCI Thesaurus.

Code C30086.

Myosin light chain kinase, smooth muscle (1914 aa, $211 \mathrm{kDa}$ ) is encoded by the human MYLK gene. This protein plays a role in both myosin phosphorylation and smooth muscle cell contraction. 